\title{
Knights of Freedom? \\ The Swedish >Order of Wallhall as a secret network of officers and the Anjala Mutiny in 1788
}

\author{
VON
}

ANDREAS ÖNNERFORS

Abstract: Dieser Artikel untersucht Zusammenhänge zwischen Vergesellschaftungsformen des schwedischen Offizierskorps und seiner Normbildung im späten 18. Jahrbundert. In den 1770 er und 1780 er Jabren bildete sich der so genannte »WallhallOrden unter Offizieren der finnischen Regimenter der schwedischen Streitkräfte. Dieser Orden diente einerseits einer raffinierten Geselligkeit und Kultivierung von Sitten und Umgangsformen, aber ritualisierte auch symbolische Narrative eines dezidiert schwedischen Patriotismus, der die schwedische Geschichte thematisierte und auf den regierenden Monarchen (Gustav III.) und seiner Dynastie als deren Vollender projizierte. Doch anlässlich des schwedisch-russischen Krieges 1788-1791 wurde die Loyalität des schwedischen Adels auf die Probe gestellt, da man die Gesetzmäßigkeit der Kriegserklärung in Frage stellte. Mebrere Mitglieder des Ordens beteiligten sich an einer gegen den König gerichteten Verschwörung, mit möglichen finnisch protonationalen Untertönen. Daher ist in der Forschung danach gefragt worden in wie weit der Wallhall-Orden diese Entwicklung gefördert haben kann. Im Artikel werden die erhaltenen Rituale des Ordens ausfübrlich präsentiert und analysiert. Dabei ist es nicht eindeutig möglich einen Kausalzusammenhang zu konstruieren. Das gesamte Ritual mit seiner narrativ-rhetorischen Struktur ist auf den regierenden König (und den Thronfolger) ausgerichtet. Bei der Nicht-Einhaltung hoch stilisierter Erwartungen vertiefte sich die Enttäuschung und spielte einer obnehin latenten Radikalisierung der Adelsopposition in die Hände.

»Secrecy $[\ldots]$ is one of the greatest accomplishments of humanity. [...] Secrecy secures, so to speak, the possibility of a second world alongside of the obvious world [...] Secrecy is a universal sociological form, which, as such, has nothing to do with the moral valuations of its content. « Georg Simmel, The Sociology of Secrecy and of Secret Societies (1906)

»The Word of the degree is >Abuse< and the password >Fall<, while we remember that when freedom, the most precious among worldly assets, is wasted or abused, it can - less than anything else - escape from fall and destruction. « ${ }^{1}$

Karl Gabriel Leinberg, Ordenssällskapet Wallhall in Skrifter utgifna af Svenska Litteratursällskapet i Finland LXXVIII 1907, Förhandlingar och Uppsatser 20, (Helsingfors, 1907), p. 361. Original archival material was sighted in the Archive and Library of the Swedish Order of Freemasons, 152.10 and 121.126 Vol. I 5. The whereabouts of these records was until recently uncertain. Per Oskar von Törne, Sällskapet Walhall och självständighetsidén i Finland (17811786) in Historisk Tidskrift för Finland (1936), 2, p. 109-110 extensively outlines his attempts to locate them properly. It was though only seventy years later the precise location was disclosed, see Kjell Lekeby, Gustaf Adolf Reuterholms hemliga arkiv från 1780-talet, (Stockholm, 2011), 
This is a quote from the rituals of the fourth degree of the fraternal secret order $>$ Wallhall<, established around 1780 among officers in Finnish regiments and at least active until the Swedish-Russian War 1788-1790. The main objective of this article is to investigate the function of values internalized in secret space in the context of publicly displayed military opposition against the war within parts of the Swedish-Finnish officer corps. In what sense did secret fraternization in peacetime contribute to the formation of ideas with potentially political implications during armed conflict? In outlining the organization, ideology and membership structure of the Order of Wallhalla, the sociological functions of secrecy will be discussed, using Georg Simmels approach in outlining a »sociology of secrecy and of secret societies « (1906).

\section{Opposition against the Swedish-Russian War}

Shortly after the declaration of war, in August 1788, 113 officers united to form the so-called Anjala Union. ${ }^{2}$ They jointly signed a petition declaring the unconstitutional character of the war and their refusal to obey royal orders. Subsequently the officers initiated unilateral peace negotiations with Empress Catherine II of Russia. This outrageous behavior immediately turned into a transnational media event. In the German press the mutinying officers were branded »Insurgents in Finland «, »Conspirators «, »Insurrectionists « ${ }^{3}$ And in response, vindications were published, arguing for the legitimacy of the actions taken. In his note to Empress Catherine II, one of the leaders of the mutiny, baron Armfeld, extensively argued that the mutineers were locked in a tension between military and civilian duties. However the "general will of the nation « was best realized in proposing to the Russian empire »eternal peace « and »good neighborhood «. ${ }^{4}$ Armfeld's note was handed over by major Johan Anders Jägerhorn (1757-1825), and it was precisely this major who had played a constitutive role in the formation of the Order of Wallhall. Seven of its members, some of them key players, actively contributed to the Anjala Mutiny. ${ }^{5}$ Yet Catherine II of Russia's response did not turn out as expected. She was pleased

p. 60. Per Gustaf Berg, Svenska ordnar, sällskaper och föreningar, m.m., (Stockholm, 1873), »Wallhalla-Orden«, p. 159-163.

2 Erklärung Sr. Majestät, des Königs von Schweden in Historisch-politisches Magazin 4 (1788), p. 1064-1073. The first extensive treatment of the Anjala-insurgents by Maunu Malmanen, Anjala-Förbundet. Bidrag till dess historia efter enskilta och offentliga handlingar, Stockholm 1848 where the Order of Wallhall is treated on p. 42-47. The claim of masonic involvement in the mutiny has recently been refuted. Göran Anderberg, Frimuraren Gustaf III, (Göteborg, 2009), p. 94-102 and 120-124.

3 Noch ungedruckte ActenStücke, die Insurgenten in Finnland betreffend in: Stats-Anzeigen 12 (1788), p. 408-413.

4 Noch ungedruckte ActenStücke, p. 408.

5 A description of the complex personality of Jägerhorn in Statsrådet Johan Albert Ehrenströms efterlemnade historiska anteckningar, Förra delen, (Stockholm, 1882), p. 25-26. A comprehen- 
to witness the mindset of the Finnish army and the decisions it had taken but felt that the hope for better neighborly relations should be expressed by a larger number of citizens. Only an »assembly of citizens « had the power to represent legal authority. And if the Russian troops would advance into Finland, she expected support from the side of the Finnish population in order to establish a legitimate civil and political existence. ${ }^{6}$ Her vague concessions seriously compromised the ambitions of the Anjala Union. This, together with minor military victories (also against Sweden's archenemy and Russian ally Denmark) and a second royal coup d'état at the Diet of 1789 implied a defeat on the side of the mutinying officers and the opposition in general. Some of them escaped to the Russian empire, others were captured and put on trial. In total 109 mutineers were convicted, a number of them sentenced to death. In the end, though, only one death sentence was enforced. ${ }^{7}$ By forging a political union with the lower estates of the 1789 Diet (peasants, bourgeoisie and parts of the priesthood), Gustav III effectively outmaneuvered the nobility, which regarded itself as the warrantor of $/ S$ wedish liberty<. It was within the nobility the radicalized opposition emerged that planned and finally carried out the assassination of the king in 1792 at the Stockholm Opera.

It has frequently been argued that the initiative of the mutinying officers was motivated by Finnish separatism, but there are few signs that it was >national in the sense of promoting the self-realization of a $>$ Finnish people $<.{ }^{8} \mathrm{~A}$ majority of the (noble) officers, many of them originating from the Swedish part of the realm, were genuinely concerned with the abuse of power displayed from the side of the crown, which they regarded as an unconstitutional declaration of war. Nevertheless, the occurrences surrounding Anjala played a fundamental role for Finland's political future. In 1809 the plan of an autonomous Grand Duchy under Russian protection was realized; Finland, for centuries constituting the eastern part of the realm, was now forever parted from Sweden. ${ }^{9}$ Since

sive biography was published by Bruno Lesch, Jan Anders Jägerhorn: patriot och världsborgare, separatist och emigrant: en tidsskildring, (Helsingfors, 1941).

6 Declaration der Russischen Kaiserin, abgesandt an die finnische Armee, durch den Major Jägerhorn. Noch ungedruckte ActenStücke, p. 411-413.

7 Gehorsamstes Memorial an das General-Kriegs-Gericht zu Stockholm in Historisch-politisches Magazin 6 (1789), p. 270-274. Anderberg, Frimuraren Gustaf III, p. 121. out of 109 sentenced mutineers, 16 belonged to the Swedish Order of Freemasons, half of them to the lodge St. Augustin in Helsingfors.

8 During the 1930-ies the presumably Finnish independency-agenda was heavily disputed in Finnish historiography. See Törne, Sällskapet Wallhall, p. 107-152; Bruno Lesch, Kring Valhalla-Ideologien: ett polemiskt inlägg in Historisk Tidskrift för Finland (1937), 1, p. 143-169. The lines of conflict developed along linguistic and cultural borders. Finnish historians argued for the function of the Order of Walhalla in promoting Finnish independency, Swedish-Finnish historians against this position. This controversy was situated in a wider contemporary, societal and polemic debate in Finland about the snegatives sides of fraternal orders, particularly freemasonry. This context might have influenced historians to de-politicise fraternal sociability altogether.

9 An overview of the development in Lolo Krusius-Ahrenberg, Finnischer Separatismus und russischer Imperialismus im vorigen Jahrhundert in Historische Zeitschrift 187 (1959), 2, p. 249-288. 
an ideology of liberty appears to have been particularly well developed among officers belonging to the Finnish regiments of the Swedish armed forces, it is legitimate to investigate possible causes of this inclination. In particular it seems to be fruitful to explore further forms of secretly organized sociability among military elites.

\section{Military elites and organized sociability in Sweden}

The affinity between military elites and organized sociability in Sweden, particularly freemasonry, is prevalent throughout the entire eighteenth century (and for a long time thereafter). Among the 4300 members of Swedish masonic lodges during the century, 28 percent can be identified as officers and these thus make out the largest portion. ${ }^{10}$ The introduction of freemasonry to Sweden in 1735 can be related to the close contacts of Swedish noble officers with their French counterparts. Service in the French military in general and in the regiment Royal Suedois (1690-1791) in particular, enhanced these mutual relations. During the Seven-Years-War, in 1761, the Swedish Army Lodge was established in Swedish-Pomerania and engaged in charitable work towards widows and orphans as well as giving decorations to and raising pensions in favor of invalid soldiers. In 1788 the workings of the lodge discontinued and it has not been entirely clarified how far the opposition against the SwedishRussian war from the side of significant parts of the officer corps potentially contributed to this development. Finnish freemasonry commenced with the establishment of the lodge St. Augustin in 1756 in Helsingfors (today Helsinki). The lodge assembled on the fortified island of Sveaborg outside the capital; sixty percent of its members belonged to the armed forces. With the installation of Carl Björnberg (1735-1790) as new Worshipful Master of the lodge in 1776, St. Augustin experienced a considerable boost. Björnberg had served for a period in the French army. During the 1750s, in the regiment Royal Dauphiné in Thionville he had been initiated into the ambulating military lodge La parfaite Union. Nine years later its Worshipful Master had signed a warrant for him to establish a sister lodge with the same name on the fortified island of Elfsborg outside Gothenburg, composed of a »second bataillon des volontaires étrangers «. ${ }^{11}$ Björnberg was a military musician, member of the Royal Academy of Music in Stockholm, of the literary order >Utile Dulci< and the convivial fraternity >Par Bricole $<$. Furthermore he established yet another masonic-like order in Sweden, >Coldinu<, a maritime order of presumably French origin, locating its mythological origin to the mediaeval Mediterranean

10 Andreas Önnerfors, Freimaurerei und Offiziertum im 18. Jahrhundert in Militär und Gesellschaft in der frühen Neuzeit 1 (2010), 1, p. 11-32.

11 Claes Ludwig Henning Thulstrup, Anteckningar till Svenska Frimureriets historia, (Stockholm, 1892), p. 33; Olof P. Berg, Frimureri i Göteborg under 1700-talet, (Göteborg, 1998), p. 40-41. 
area. ${ }^{12}$ As member of the enlightened Christian organization »Pro Fide et Christianismo «, Björnberg worked to improve the (sometimes strained) relationship of the lodges to the Swedish state church.

Throughout the eighteenth century a number of further secret societies or branches thereof were established on the fortified island Sveaborg, for instance the >L'Ordre de Charpentier' (Timmermansorden), also established during the Seven-Years-War and deducing its origin to the reign of Elizabeth.$^{13}$ The Charpentier mother lodge in Stockholm was named 'St. George and in 1763 issued a warrant for the establishment of a lodge on Sveaborg. This lodge, sSt. Charles<, existed until 1808 and initiated no less than 442 members. Together with other records, the index of members was returned to the still existing (2013) mother lodge in Stockholm that however refuses entry to its archives. Against this background it is not surprising that yet another fraternal order, Wallhall, could establish itself among the Swedish-Finnish officer corps. Multiple memberships were not unusual. Apart from Björnberg, another elucidating example is Hans Henrik An[c]karheim (born Grise, ennobled in 1772, 1743/48-1814), who in his official curriculum vitae lists membership in the Order of Carpenters, Freemasonry, The Old Goths, The Order of the Amaranth, Coldinu and the Order of Alexandrine. ${ }^{14}$ Possibly a case like Anckarheim remains an extreme exception, however by comparing membership records of three fraternal orders in Sweden, hundreds of multiple memberships have been detected, awaiting further research. ${ }^{15}$ The different forms of organized sociability appear to have catered for different needs within the officer corps. Freemasonry, the Carpenters and Coldinu promoted moral values, drawing from Christianity, ancient and modern philosophy paired with hermetic traditions. >Par Bricole<, as its name stipulates, engaged in pure convivial entertainment, in a carnivalesque caricature of the fraternal order as the ideal type of respected sociability. And finally Wallhall served the promoted performed political and patriotic maxims of Swedish history and present time. A contemporary witness described the function of these associations as follows:

The business of the Order allowed brethren, particularly the younger, a useful pastime and prevented them from pernicious entertainment, which younger officers in garrisons frequently indulge in. For them [the members of the Order] life in the Corps de Garde, intercourse with debauched women or participation in carousals was an unknown pastime that was considered with disdain. Their interest was

Berg, Svenska ordnar, »Coldinu-Orden«, p. 565.

Berg, Svenska ordnar, »Timmermansorden«, p. 607-611.

14 Kungliga Biblioteket Stockholm, Biographica A, »Ankarheim «.

15 While working on Jonas Andersson and Andreas Önnerfors, Förteckning över svenska 1700-talsfrimurare in Mystiskt brödraskap-mäktigt nätverk, studier i det svenska 1700-talsfrimureriet edited by Andreas Önnerfors, (Lund, 2006), p. 154-282 the transcribed membership record of Swedish masonic lodges of the eighteenth century was compared with records from the Order of Carpenters and Par Bricole. Social historian Anders Simonsen has identified a similar pattern in his micro study on organized sociability in Gothenburg. Anders Simonsen, Bland hederligt folk. Organiserat sällskapsliv och borgerlig formering i Göteborg 1755-1820, (Göteborg, 2001). 
exclusively directed towards serious matters, reading, composing orations and treaties as well as discourses on moral and political issues. ${ }^{16}$

\section{Establishment and organization of the Order of Wallhalla}

The foundation of the Order is treated in the rituals to the fifth degree where it is stated:

At the time when Stockholm was inundated with a number of smaller fraternal orders, a group of noblemen gathered, encouraged by the honor to establish a society among themselves, founded with precious aims. This decision was carried out. The society [the original has "gille«, guild] quickly grew to a number of 100 members, and the order called La Constance. With such a happy prospect it was decided to erect a lodge on Finnish territory [...]. ${ }^{17}$

When this exactly happened cannot be established, but founding is believed to have occurred between 1772 and 1782. The Order La Constance was most probably erected by Count Gustav von Paykull (1757-1826), an enigmatic character, author, zoological collector and also a member of the literary order Utile Dulci (1766-1795) to which belonged a substantial number of officers. Per Oskar von Törne has come to the conclusion that the culture of Wallhall, particularly the design of degree ceremonies as much as its rhetoric exhibits clear parallels to Utile Dulci. ${ }^{18}$

The initiative to establish a lodge of La Constance on Finnish soil was taken by the above-mentioned Jägerhorn (at that point in time captain in the Karelian Dragoon Regiment). At this occasion its name was switched to »Wallhall« in order to signal a support of patriotic history, particularly of the most recent past in accordance to the so-called `Gustavian< époque (1772-1792). In line with this reading, the strengthening of royal power following the coup d'état in 1772 was celebrated as a restoration of political order; the immediately previous so-called >Age of Liberty< (1738-1772) was stigmatized as an era of confusion, partisanship, and foreign corruption. Nevertheless did the concept of liberty occupy a prominent position within the (ritually staged) rhetoric of the order, which during the Swedish-Russian war might explain the transfer of ideas to parts of the radicalized opposition to Gustav III amongst the nobility. Hence it is legitimate to ask how values that were enacted and reinforced in secret space potentially impacted action in public space, cautiously avoiding conspiracist patterns of causality. Furthermore it is worthwhile to stress that the society explicitly referred to motifs of Nordic-Scandinavian mythology and

16 Ehrenströms historiska anteckningar, p. 26. [Translation by the author]

17 Leinberg, Ordenssällskapet Walhall, p. 366 [Translation by the author]. See also Lolo KrusiusAhrenberg: Tyrannmördaren C.F. Ehrensvärd, (Stockholm, 1947), p. 54-55 and 93-95.

18 Törne, Sällskapet Wallhall, p. 119-122 and Krusius-Ahrenberg, Tyrannmördaren, p. 95 and 99. Herein also treated parallels to other Orders and fraternities. 
history (and not Finnish), which is mirrored in its internal terminology and the backdrop of motifs. The chosen name of the order, to be interpreted as a reinforcement of a heroic pathos among the officer corps, is characteristic in this regard:

The name of the Order Wallhall refers to the old times; how our ancestors termed the home of the blessed after death is amply known, but we have seen ourselves occasioned to add this name to our society since such as our heathen ancestors only after death were allowed to taste the beatitude mentioned, so has also our fatherland after many heavy and bitter commotions finally witnessed its happiness fortified. ${ }^{19}$

This apparent reception, treatment and ritualization of an >old Norse (outspokenly pagan, non-Christian) set of motifs takes place parallel to a renaissance of > Gothicism< under Gustav III, the national myth supportive of the state of the Swedish Age of Great Power (1632-1718). >Classic < Gothicism in combination with orthodox Lutheran state religion can be ascribed a civilizing function for the formation of identity during the establishment of the Swedish Great Power during the seventeenth century. ${ }^{20}$ Its revival at the end of the eighteenth century aimed predominantly at reinforcing proto-national and patriotic-political virtues. In this process it is possible to trace a pre-romantic influence manifesting itself later with >Neo-Gothicism $<$ and $>$ Scandinavianism $<$ in the early nineteenth century (and its particular forms of sociability). ${ }^{21}$ For a proper understanding of the rituals of the Order of Wallhall and the values ascribed to ideal representatives of Norse imagination this is a crucial point since it ties into the prevalent political mythology of the time. If intended or not, Norse references enacted in secret space could potentially occupy a political meaning.

The order was divided into five consecutive degrees with chivalric-Nordic references titled: manly junior squires, explorative and gallant squires, enlightened and toughened knights, fair counts and warlords (Jarlar och Drottar). The first two degrees were subordinated to the third degree of chivalry. Jarlar and Drottar are titles from the old Norse nobility. Superior to all the degrees was the commanding Drott, the founder of the order and its superior lawspeaker (an independent judge). ${ }^{22}$

Ten provinces of the order constituted the so-called Commanderier, corresponding to the historical provinces of Finland. Each Commandery was lead by a so-called Wallfauder (taken from a side-name of the god Odin), the responsibilities of which where listed diligently. ${ }^{23}$ Among other duties it was expected to know the health status and whereabouts of individual members, to be communicated quarterly to the central leadership in Helsingfors. Letters from the registry were to be headed as orders, »with the intention to make the

19 Leinberg, Ordenssällskapet Walhall, p. 341 [Translation by the author].

20 Erik Ringmar, Identity, interest and action - a cultural explanation of Sweden ss intervention in the Thirty Years War, (Cambridge, 1996) engages extensively in a discussion of ideas supportive of the Swedish state.

${ }^{21}$ See also Törne, Sällskapet Wallhall, p. 122-123.

22 Leinberg, Ordenssällskapet Wallhall, p. 342.

23 Leinberg, Ordenssällskapet Wallhall, p. 369-371; Törne, Sällskapet Wallhall, p. 132-134 and 136. 
execution of commands of the order in a military fashion, which is well adapted to a noble society that still is constituted out of young officers. $\ll^{24}$ The regulations also stipulated that secret correspondence between members was to be composed in cipher for which keys were distributed. Unfortunately none of these letters have been preserved, but it is important for our understanding of practices among secret networks in the military that encrypted communication did exist. Members gathered monthly in order to initiate new candidates and present discourses. An annual assembly took place on $18 \mathrm{March}$, at which orations and obituaries were held. ${ }^{25}$

\section{Membership of the order}

Around twenty members constituted the leading echelons of the Order that was exclusive to officers from the nobility. ${ }^{26}$ In total, membership is said to have amounted to one hundred, quite an impressive figure that however also has been questioned. From various sources it is possible to extract names and data related to 32 of the members. ${ }^{27}$ Their average age in the year of reference 1788 was 37,5; a majority had as (young) adults experienced the transition from the Age of Liberty to Gustavianism. Many of them were already recruited to active military service during childhood and were related through kin. Furthermore, comparison to membership records of two other fraternal orders (freemasons and Carpenters) reveals informative overlaps. Since however the membership record of the >Hut of St. Charles< of the Order of Carpenters in Sveaborg is inaccessible, it was only possible to consult a membership list from the >Hut of St. George in Stockholm, printed in 1911. In this list only members that moved from Finland to the Swedish capital and had reason to switch affiliation are registered. ${ }^{28}$ Thus, five members can be identified as carpenters, four of these also as freemasons, which implies a contemporary multiple membership in different fraternal orders. Most probably the overlap is far higher. Almost half of the members, thirteen, were also freemasons, mainly in the lodge St. Augustin. Double or triple membership thus constitutes no exception. Seven of the members (two of them freemasons) actively engaged in the Anjala mutiny, some of them left the country for the Russian empire following the collapse of opposition against Gustav III.

${ }^{24}$ Leinberg, Ordenssällskapet Wallhall, p. 370.

25 Leinberg, Ordenssällskapet Wallhall, p. 343; Törne, Sällskapet Wallhall, p. 131-132.

26 Records in Leinberg, Ordenssällskapet Wallhall, p. 346-350 and Törne, Sällskapet Wallhall, p. 130-131.

27 Armas Gräsbeck, St. Johannes Logen St. Augustins Matrikel 1762-1808, (Helsingfors, 1954); Önnerfors, Förteckning.

28 Svenska Timmermanshyddans af S:t Georgii minnesskrift utgiven till firande af dess 150-åriga bestånd 1761-1911, (Stockholm, 1911). 


\section{Death in Capitolium: the fourth degree of the Order}

It emerges from the explanation of the name of the order that it (like its predecessor in Stockholm) dealt with the immediately elapsed history of the Swedish people. This was partly performed within the rituals of initiation (of which only the fourth and fifth are preserved), partly on the occasion of anniversaries and commemorative orations. The symbolic culture of the Order, as much as the staged rhetoric of the rituals reveals a blend of typically enlightened political ideas with classic, in particular Roman history, (imagined) motifs of Norse mythology and events of Swedish history. The interior design of the assembly room of the fourth degree represents the Capitolium in Rome; members of the order are dressed as senators. Two guardians play the role as >lictores $<$ with their symbols $>$ fasces $<$ and $>$ secures $<$ Q Questions and answers between President $(\mathrm{P})$ and Master of ceremonies $(\mathrm{MoC})$ open the ritual:

$[\mathrm{P}]$ My brother, on which foundational pillars rests our sacred Capitolium? [MoC] Zeal for the good of the fatherland, virtue, honor, and righteousness constitute the solid rock upon which our felicity rested. [P] What has shaken our principles and our calm? [MoC] Egoism, Injustice and Liberty abused [P] How are the brethren most certainly convinced of the dangers that prepare the fall of our fellow citizens, when the spirit of persecution is allowed to reign and innocence lacks of protection that is warranted by law? [MoC] Examples always speak with the largest persuasion. ${ }^{29}$

This passage illustrates already the general tone and message of the ritual: a patriotic pathos, hints at abuse of political virtues and values as well as the idea expressed that fundamental rights are enshrined by law. Furthermore one can read the last line as a meta-comment to rhetorical figures (the persuasive power of sexemplum<) and what follows: ritualized rhetoric. With the words »it is unique to humanity to continuously seek greater clarity, more discretion and progress on the slippery course of felicity « the initiation of a »tribune « to senator is prepared. Without going into too much detail, the subsequent ritual consists of three parts. In the first part the candidate is asked about his attitudes towards patriotism and »lawfully warranted liberty « and is led into the assembly hall where the positive attitude of the tribune is reported to the "powerful brother dictator «. The candidate is allowed to sit down at the council and is told that another senator recently had been excluded and now an appropriate punishment had to be decided upon. Therefore the new senator is asked to reply to the question: "Should a triumvirate rein Rome? Or is it preferable that the people are intervening in government? « Regardless of reply, the senate declares strong discontent and the candidate is accused of sharing the opinion of the recently excluded senator. In expectation of an instant punishment the candidate is led away by the lictores and - in manacles - placed into a dark room.

29 Törne, Sällskapet Wallhall, p. 125 [Translation by the author]. 
Thereafter the second part of the ritual unfolds. After a while the dictator proclaims the verdict: on the basis of his thoughts about the political organization of the city, the candidate has revealed himself an enemy of Rome and consequently is sentenced to death, to be executed immediately by the hierophant. In yet another room the candidate is presented with a coffin, an opened grave, an executioner's axe and a block. On the altar burns an »eternal fire represented by a blue flame « and behind it stands the hierophant in full regalia »and papal headgear". In the following the candidate is addressed by the hierophant with a speech on the caducity of life, the partition of soul and body, and the unpredictability of death. He is congratulated for his imminent passing: »Farewell my friend, may your soul be surrounded by the clarity of the immortal, and may we meet again in happiness and candor in the glorious sites of the blissful. $\ll^{30}$ Hereupon one of the lictores grabs the axe and the candidate is blindfolded. Wind instruments play a well-known Swedish psalm serving preparation for death. Arriving at the second verse, the $\mathrm{MoC}$ asks the Capitolium if the sentence is to be enforced or if there are any reasons to annul it. The President declares that this is the case, the "sufferer « is to be led into the Capitolium »in order to indulge in the reward that his constancy appears to have rightfully earned. $\ll^{31}$

Now the third and last part of the ritual is enacted. The candidate is liberated from shackles and blindfold in order to receive the salute of the Capitolium. The constancy of the sufferer in his danger is hailed, the candidate has to take an oath that confirms loyalty and friendship towards the Order. $\mathrm{He}$ is given the token of the new degree and admonished to reflect upon the »inconstancy of happiness «. Referring to the recent mock execution the candidate is inculcated that "no one is to be suspected or sentenced on loose grounds", whereupon his initiation to Patrician is completed.

In the subsequent explanation of the fourth degree the candidate is informed that its Roman design aims at an expression of the >Age of Liberty< of other states in general and of Sweden in particular. Commemorating this period could however unfortunately not happen without describing its negative traits. Questioning the candidate served to exemplify two ideal positions: >Brutus representing the party that wants to reduce royal power and >Caesar< representing the party that rather aims at enlarging royal power than decreasing it. It did not matter how the candidate replied. He was sentenced to his suffering as an illustration of the former confusion of party rule: quick changes in their policies occasioned criminalization and persecution of dissidents. It is remarkable that considerable critique is directed against the aristocracy itself, which was said to have been united by »maleficent hearts and affinities «, governing with » evil intentions and self-interest «, throwing the realm into a »sea of misfortune «, using »against defenseless fellow citizens arbitrary violence, since the law no longer had power to protect the innocent. $\ll^{32}$ This passage of the ritual

30 Leinberg, Ordenssällskapet Wallhall, p. 357.

31 Leinberg, Ordenssällskapet Wallhall, p. 357.

32 Leinberg, Ordenssällskapet Wallhall, p. 360. 
refers to the fact that the Council of the Realm, in which for decades leading aristocrats were represented, during the Age of Liberty self-confidently assumed ultimate power over the affairs of the country, jeopardizing both royal and representative power. From a close reading of the ritual it emerges how recent political history and performance in secret space are interwoven.

\section{»Born for the fatherland «: the supreme degree of the Order of Wallhalla}

In the fifth and supreme degree of the order, the assembly room is in confusion. ${ }^{33}$ When the candidate enters the room, four persons surround the president and attempt to grab his gavel, all talking about wanting to assume power. The president is forced to restore order and - together with other brethren present - pulls his rapier. Thereafter the four agitators are led into another chamber that is in good order and illuminated; the chair of the president transformed into a throne with a canopy. A new figure reveals himself as a lawspeaker titled »Allshärjare Domare «, dressed in ancient garb. Wallhall-brethren carry bucklers and swords and form a circle around the lawspeaker. Receiving consent in treating the agitators mildly, the president is placed on a throne with canopy and the rioters are pardoned. Now the assembly room is even more illuminated: »A banner with Apollo's Lyre next to two Famae [...] and a number of laurel wreaths « is presented and the judge declares: »My brethren, time has come to reveal the concealed. $\aleph^{34}$ The candidate is sent to get the »Book of Fate and is asked to read out the destinies of the future. These prophecies gravitate primarily around the fatherland and monarchy and their brilliant and rich future, reinforced by appraisal of the Royal coat of arms and the date 1 November 1778, the birth date of the future heir to the throne Gustav Adolf. In this context the terms »felicity «, »fellow citizen « and »philanthropy « are used repeatedly. The candidate receives a token of the degree, a radiant sun with the initials of the king and crown prince. An intercession for the Swedish realm ends the ceremony of the fifth degree, which is explained subsequently.

First of all the history of the Order is told to the candidate along the previously mentioned lines. The candidate is again informed that the fourth degree symbolized the era of confusion, peaking with the beginning of the fifth degree, representing the disorder of the Diet of 1771 and the »outrageous desire of the Estates to rule«. The arrest of the agitators alludes to the empowerment of the king in 1772: »lawlessness and confusion prevailed, whereupon a mild king saw himself obligated to save his subjects. $\ll^{35}$ The figure of lawspeaker is interpreted as a symbol of »enlightened reason « and connected to the Norse prac-

\footnotetext{
Törne, Sällskapet Wallhall, p. 125-127.

Leinberg, Ordenssällskapet Wallhall, p. 363-364.

Leinberg, Ordenssällskapet Wallhall, p. 367.
} 
tice of thing assemblies. To knock the swords against the buckles is explained as an age-old practice, a symbol of the people's voice, consent to royal power and mildness towards the agitators. It is a privilege of enlightened reason only to read about the nation's future and a particular happiness for the Order is to commemorate the birth of the crown prince. The white color of the ribbon symbolizes " purity and candor, for ever a hallmark of virtuous fellow citizens «. In the explanation to the fifth degree there are mentioned elements from previous degrees the rituals of which not have been preserved. For instance mention is made of a rock during the first degree »denoting constancy on which rests an empire with a well-founded form of government «. Furthermore it is revealed that the black dress of the order carries white letters $\gg F F$ for »födda för fosterlandet «, born for the fatherland. ${ }^{36}$ It is also related that the first three degrees aim at homage of three kings from the house of Wasa. Such a reading corresponds well to the established rhetorical figure, a triad of »Gustav Wasa - Gustaf II Adolf - Gustav III « reproduced permanently in occasional poetry, banners and royalist orations during the Gustavian period. All three of them were styled as >saviours< in apologetic historiography: of the nation, of pure Protestant belief and of liberty. ${ }^{37}$

Apart from these two rituals of the Order, an oration delivered in 1784 is preserved in its entirety. Orator Carl Henrik Klick (1753-1808), later on an active member of the Anjala mutiny, outlined the biography of the presumed national liberation hero Engelbrekt who in 1434 led a Swedish uprising against Erik of Pomerania, the Danish King of the Nordic Kalmar Union. ${ }^{38}$ Engelbrekts actions (real and imagined) have in their history of reception been hailed as an expression of the love of liberty, deeply rooted within the Swedish people. Klick's oration fits within the framework of officially sanctioned patriotic rhetoric in Sweden at the time. However it is also possible to read some of the passages as a philosophical justification for an uprising against a tyrant, the >contrat social < and svolonté général<, underpinned by references to not uncontroversial political thinkers such as Raynal and Rousseau. These potentially radical ideas were intertwined with a glorification of the heathen past of Sweden as morally superior (at least in comparison to the subsequent epochs of Catholic Christianity and political bondage). From Klick's perspective, Engelbrekt's fight for national liberation is placed in between Norse snaturak freedom and enlightened concepts of liberty, in stigmatized smiddle ages of fanaticism, self-interest, prejudices and passivity towards despotic suppression and foreign rule. Although most likely unintended in 1784, the juxtaposition in Klick's oration between >despot< and ssuppressed might well have served as a figure of thought when four years later radicalized parts of the opposition prepared the ground for action against the monarch.

36 Leinberg, Ordenssällskapet Wallhall, p. 368.

37 Andreas Önnerfors, Svenska Pommern - kulturmöten och identifikation 1720-1815, (Lund, 2003), p. 120, 255, 261 where this motif is treated extensively. See also Peter Hallberg, Ages of Liberty, (Stockholm, 2003), where the usage of the triad in political rhetoric is explored further.

38 Bruno Lesch, Wallhallsbrodern C.H. Klicks äreminne över Engelbrekt in Historisk Tidskrift för Finland (1936), 2, p. 153-182. 
In 1786 a fictive letter presumably written by the lawspeaker Thorghny Thorgnysson (mentioned in the Icelandic sagas) circulated in Sweden. ${ }^{39}$ This pamphlet - translated from >Gothic and written in Wallhalla - is directed against king Gustav III, accused of mismanaging the legacy of Swedish national history. Thorghny attacks the negative character of the king and predicts a disastrous future: the Swedish realm is in great danger, power is abused, the executioner's axe is not far, the blood of the people is shattered in domestic conflicts, the future of the crown prince contested. Against the backdrop of factual political events in Sweden 1786-1809 this fictive letter reads as a shockingly realistic scenario. And even if it cannot be ascribed to the circles around Wallhall, it hints at the potential explosive force of an idealization of the Norse complex of motifs. From the morally superior past and the afterworld a warning is issued by the powerful figure of a lawspeaker, the archetype of a personification that also appears prominently in the rituals of Wallhall.

\section{Ritualized patriotism, patriotic ritual}

Those who designed these rituals without doubt possessed a considerable performative competence. Spatial and temporal events, motifs, symbols and objects, dialogues and physical experiences are used in order to create an effective performance using sensations (music, light/darkness, interior design), emotions (fear, threat, pleasure) and philosophical reflection (stoicism, death/ vanity, religious references). Costumes (Roman senators/Norse lawspeaker) and attributes (stick/sword/buckle) intensify this effect further. The horizon of interpretation against which ritual performance and its progression are displayed can be deduced from a reductionist imagination of Swedish history (e.g. the triad of saviors) and in particular imminent contemporary history (past confusion - present order - future felicity). Against the backdrop of this narrative structure, the ritual is constructed around an ethics (as established in other fraternal orders) within which ancient/pagan motifs, Christian elements and the philosophy of enlightenment are placed on an equal level and blended with each other. A peculiarity of the Order of Wallhall is its clear reception of the Norse complex of motifs as well as conscious references to contemporary history. The unique difference between Wallhall and other Orders is the explicitly political-historical and patriotic-national orientation of the former. Even if other fraternal orders aligned with the authorities, nourished patriotism or identified with the Swedish realm, this was not the main object of their ideology, symbols and rituals. Herein lies the special profile (and potential attraction) of Wallhall in comparison to other fraternal orders. To this is added

Leinberg, Ordenssällskapet Wallhall, p. 372-374 prints a copy from the university library in Helsinki. Another manuscript copy is also found in Lund university library (here assigned to documents of the Anjala mutiny), which points at circulation in the entire realm. 
a particular interpretation: nobility (from which members are recruited among the military elites) is portrayed as the primary sustainer (but also potential usurper) of political order in the Swedish realm and its exceptional position stressed by (almost exaggerated) loyalty to monarchy. In this sense the rituals can be interpreted as a highly political statement within the domestic disputes of the Swedish realm. When this worldview collapsed during the diets of 1786 and 1789 and the Swedish-Russian war it is no surprise that a couple of members of the Order, possibly encouraged by a ritualized patriotism of nobility, claimed to represent $>$ Swedish freedom/liberty< and - as self-styled warrantors of this freedom - drifted to the camp of radical opposition. ${ }^{40}$ As the case of the Order of Wallhall demonstrates vividly, the relationship between secret and public space within the sociability of military elites is complex.

\section{Secrecy as a principle of eighteenth century (military) sociability}

What fraternal orders of the eighteenth century had in common was the paramount function of secrecy in a variety of forms. This function falls largely into two categories: a psychology of inclusion (internal group dynamics) and the necessity of exclusion (external demarcation). While the existence of the orders was more or less known in public, membership, rituals and activities generally were not. In the case of Wallhall inclusion was created by the very design of an initiatory society together with particular forms of internal arcane practices such as taking an oath of taciturnity or communication in cipher. The Order also established a clear demarcation between itself and the outside sprofaner world. In examining the sociological foundations of secrecy and secret societies, Georg Simmel outlined a number of factors. First of all, when a "group as such seizes upon secrecy as its form of existence, the sociological meaning of the secrecy becomes internal. $\ll^{41}$ Secrecy constitutes and determines reciprocal relations within the group. In particular the establishment of mutual confidence, »the ability to preserve silence « is a constitutive factor (frequently demanded by taking an oath) in a tension between faith and potential betrayal. By sharing and keeping secrets, Simmel argues, »societies have exerted a highly efficient disciplinary influence upon moral accountability among men. ${ }^{42}$

Peculiar to the workings of secret societies is the internal grading of members. Almost all fraternal orders of the period (also the Order of Wallhalla) follow the principle of gradual and consecutively, increasingly growing or deepening initiation. ${ }^{43}$ The principle of initiation through ritual ties into ageold hermetic practices already found in the mystery cults of antiquity. To be-

\footnotetext{
40 Törne, Sällskapet Wallhall, p. 149-150.

${ }^{41}$ Georg Simmel, The sociology of secrecy and secret societies in The American Journal of Sociology, 11 (1906), 4, p. 472.

42 Simmel, The sociology of secrecy, p. 473.

43 Simmel, The sociology of secrecy, p. 488-489.
} 
come a member of an Order required a ritual of primary initiation. Subsequently, following an inner spatial-temporal logic built into the underlying narrative structure of the ritual, further degrees are given, the candidate climbs higher or progresses deeper into knowledge along typical moral exemplifications, for instance to >overcome mortality ( as in the fourth degree of Wallhall) or to >resist temptation<. Almost all orders have also a supreme degree; there is a ritual end to the quest where ultimate enlightenment is enabled. It is possible to claim that the degree structure was attractive to the military elites in that it reinforced and supported the concept and practice of military rank.

For Simmel, ritual is an expression of emancipation of the secret, differentiating it from open society, representing »extreme freedom and opulence of form « and »detachment from the norms of the circle which contains it«, since no external authority can tell the society what to perform. ${ }^{44} \mathrm{~A}$ paradox is however that even if a secret society owns complete freedom in this regard (research speaks of ritual dynamics), ritual represents possibly one of the most rigid forms of coordinating collective actions among human beings, reinforced by its script-bound iterative nature with few deviations, little room for improvisation and a strict division of labor. In this quality, eighteenth century ritual is very much like baroque/classical music, allowing for hardly any variations but yet $>$ free within the (time-specific) rules of composition. Simmel claims that the »fixedness and detail of ritual serve to counterbalance « a too extreme tendency towards freedom, a »constraint as counter-influence. $\ll^{45}$ To the ultimate freedom of designing a significantly different epistemology through ritual must be added its performative character without which it only partially can be understood. The radical difference between ritual and text lies in performance. When reading and summarizing rituals (such as those of the Order of Wallhalla), an outside observer without performative competence or strong imagination will not be able to immediately grasp temporal, spatial and bodily dimensions. These are only revealed in their entirety when the ritual is performed, much like a musical score. Since the formation of values through experienced ritual are part of the epistemology of the secret, it is paramount not to divulge its content. For educational reasons it is believed that any revelation will diminish the effect of direct experience, hence initiation into secret knowledge is impaired.

Simmel identifies this function as a contribution towards a »life-totality« that he also associates with military and religious careers. ${ }^{46}$ This may help to explain the affinity between military elites and secret societies. For Simmel they are similar in formalism and hierarchy, in the sense of demanding the whole human being in her »organic completeness «. Yet another factor appears to be significant in this context. To claim access to ssecret< knowledge is always a claim of superiority and privilege: »secrecy and pretense of secrecy (Geheimniskrämerei) are means of building higher the wall of separation, and therein a

Simmel, The sociology of secrecy, p. 480 and 483.

45 Simmel, The sociology of secrecy, p. 482-483.

46 Simmel, The sociology of secrecy, p. 481-482. 
reinforcement of the aristocratic nature of the group. $\ll^{47}$ For a society recruiting its members among noble officers, the ssecret thus represents a factor of reinforcing the value of nobility (and the martial values associated with it), particularly in the rituals of the Order of Wallhall that enacts the privileged nature of this estate in the Swedish realm..$^{48}$

In other words, the secret occupies a function in forging a group, a particular epistemological capital is created in the very moment secret knowledge is claimed, credibly enacted and disseminated (for instance through ritual performance). While this force - by offering confidence and protection - is internally binding, it immediately and simultaneously establishes exclusion towards those who not are in possession of the secret, »in antithesis with the wider association included within the greater society « and »detachment from that totality as the unavoidable technique for its purpose. ${ }^{49}$ Certain subjects are concealed from general knowledge, "a body of doctrine to be kept from publicity. ${ }^{50}$ According to Simmel, the apartness of this knowledge represents a >note of freedom: »In exercise of this freedom a territory is occupied to which the norms of the surrounding society do not apply. The nature of the secret society as such is autonomy " with the potential danger of anarchy. ${ }^{51}$ Within the Order of Wallhall, similar to many other fraternal orders of the period, the outside world is labeled the sprofane world, left outside the sanctuary within which secrecy is practiced and staged. To draw lines of separation, secret societies develop »complicated signs of recognition « and regulations of how to talk in public. $^{52}$

Secrecy is as strong as its weakest links. Simmel explains that semi-secret societies (e.g. whose existence is known) have more power to resist interruption or disclosure than those that are immediately dependent upon remaining secret (such as a criminal conspiracy). This helps to understand the tension between >opacity and transparency< that can be observed for instance in the history of modern freemasonry. ${ }^{53}$ From its outset in urban London of the late 1710s, freemasonry has been openly discussed in the press, its rituals and ideology revealed. But despite of transparency and publicity, freemasonry attracted vast numbers of membership and maintained to nurture (practices of) secrecy. This developed only into a problem when publicly available knowledge was married with the figure of political conspiracy theories, particularly since the time of

47 Simmel, The sociology of secrecy, p. 486-487.

$48 \mathrm{Up}$ to the end of the eighteenth century, the Swedish officer corps was almost exclusively recruited among the nobility. Interestingly, this pattern changed after the Swedish-Russian war in favour of commoners joining the ranks of commanding officers. See Sten Carlsson, Standssamhälle och ståndspersoner 1700-1865, (Lund, 1949), and Fredrik Thisner, Militärstatens arvegods. Officerstjänstens socialreproduktiva funktion i Sverige och Danmark, ca 1720-1800, (Uppsala, 2007).

49 Simmel, The sociology of secrecy, p. 484.

50 Simmel, The sociology of secrecy, p. 477.

51 Simmel, The sociology of secrecy, p. 482.

52 Simmel, The sociology of secrecy, p. 485.

53 Kristiane Hasselmann, Die Rituale der Freimaurer. Zur Konstitution eines bürgerlichen Habitus im England des 18. Jahrhunderts, (Bielefeld, 2009), p. 145. 
the French revolution..$^{54}$ Due to the relative value of secrecy, Simmel argues »the secret society is the appropriate social form for contents which are at an immature stage of development « in »ascending movements «, a »transition stadium between being and not-being. ${ }^{55}$ Without discussing the ideology of the Order of Wallhall further here, this appears to be an appropriate description. The notion of sfreedom $<$ plays for instance a prominent role in the rituals of the Order, however at a time when it still is open for different interpretations and claims. It is first in the environment of an ever more alienated Swedish opposition, freedom turns into the more powerful concept of spolitical liberty< with constitutional implications. The same applies for the understanding of rrevolution<. Whereas King Gustav IIIs coup d'état in 1772 was hailed as a revolution, the concept of revolution< had lost its attractive appeal for large parts of reform-oriented minds in Europe at the latest with the Reign of Terror in 1794. All these phenomena unfold under what Reinhart Koselleck has called the sSaddle Period between 1750 and 1850, when major historical terms and basic concepts underwent significant changes. ${ }^{56}$ Possibly this period of reconceptualization was influenced by the secret as a cipher and counter-space for the expression of visions yet to be realized. In discussing the function of secret societies as a protection against the oppressive state of Ancien Régime fashion, Koselleck himself stated: »From the outset Enlightenment and Secret appear as a historical twin pair. ${ }^{57}$ Also Margaret C. Jacob ascribes masonic lodges of the eighteenth century an important function as »schools for government «, where members could practice elections, registration of members, collection of membership fees, decision on expenses for philanthropic purposes and oratory skills, all necessary tools to operate in a participatory political culture that still was to come..$^{58}$

Yet another protective function of secrecy as outlined by Simmel deserves to be discussed in the context of the Order of Wallhall. He claims that »the secret society emerges everywhere as correlate of despotism and of police control. It acts as protection alike of defense and of offense against the violent pressure of central powers « and later: »widespread existence of secret societies is a proof of public unfreedom. ${ }^{59}$ Whereas it holds true that central powers, worldly and spiritual alike, throughout the centuries have felt offended by forms of association that they cannot control, in particular of a >secret $<$ nature, the >correlation to despotism < has to be somewhat modified. Oppressive ideological and political systems necessitate the formation of secret space and forms of association adapted to secrecy as counter-space(s) of resistance (hence, the existence of a ssecret $<$ fraternal order among officers could be interpreted as a

54 John Roberts, The Mythology of the Secret Societies, (London, 2008).

55 Simmel, The sociology of secrecy, p. 471-472.

56 Geschichtliche Grundbegriffe. Historisches Lexikon zur politisch-sozialen Sprache in Deutschland. Eds. Otto Brunner, Werner Conze, and Reinhart Koselleck, (Stuttgart, 1972-1993).

57 Reinhart Koselleck, Kritik und Krise: eine Studie zur Pathogenese der bürgerlichen Welt, (Frankfurt a.M., 1973), p. 49.

58 Margaret C. Jacob, The Origins of Freemasonry. Facts and Fictions, (Philadelphia, 2006), p. 9.

59 Simmel, The sociology of secrecy, p. 472 and 483. 
response to such oppression). It is also therefore oppressive regimes and central powers (such as fascism and state socialism) were particularly eager to eradicate all forms of sociability that ran contrary to their totalitarian claims to monopoly of (mass) organization. ${ }^{6}$ Projected upon the case of Sweden, it appears that the more oppressive the rule of Gustav III turned at the end of the 1780s, various forms of association rather decreased (such as the Order of Wallhall).

Paradoxically however it emerges that the highest amount and richest variety of secret societies (and those nurturing secrecy as a form of epistemology) exist in >open< societies. It is in Hanoverian Britain, with a strongly developed constitutional and parliamentary culture, the world of lodges, clubs and associations originated and boomed. It was during the Swedish >Age of Liberty< (1738-1772) a significant number of fraternal Orders (in several cases still existing today) were established. Finally, in the United States the largest variety of such organizations developed during the century to come. Also for the development of French political culture, freemasonry and related organizations played a constitutive role. Adding to this paradox, following Simmel, it is in the most open societies the ritual of secret orders is the strictest: »It is characteristic that, among the Freemasons, it is precisely the Americans - who enjoy the largest political freedom - of whom the severest unity in manner of work, the greatest uniformity of the ritual of all lodges are demanded. « ${ }^{61}$

Why would relatively open, transparent and participatory forms of rule with a well developed public space encourage the existence of discrete, opaque and selective forms of association in private/secret space? The only reasonable answer lies in the proposition that it is a matter of mutual trust between power and citizens. Tolerance of secrecy can only be accepted if power does not perceive any threat and to the contrary when voluntary association among citizens does not fear persecution from power. It is then that secret space turns into creative space that enables societal innovation.

The mere existence of a secret order among officers during the reign of Gustav III does hence not automatically stipulate a »correlate of despotism . It is also not sure that the purpose of the order was to prepare future political action covertly, under the veil of secrecy. Rather, the formation of a secret order within the Swedish officer corps takes place in the ambiguous space of trust between ruler and ruled. Internalized values and ideas expressed live an independent life from the existence of the organization within which they are expressed and cultivated.

It was the aim of this article to investigate the relation between secret sociability within Swedish military elites and the formation of norms. This relationship is however not easy to establish and cannot be reduced to simple models of causality and interdependency. In her study of British masonic ritual of the eighteenth century, theatre scholar Kristiane Hasselmann points out its function for the formation of a particular sethics of habitus $<{ }^{62}$ An iterative episte-

60 Simmel, The sociology of secrecy, p. 497-498.

${ }_{61}$ Simmel, The sociology of secrecy, p. 483.

62 Hasselmann, Die Rituale, p. 15. 
mology of ritual, of personal, bodily and sensual experience establishes an intensified internalization of values transmitted. If this also holds true with the Order of Wallhall, the frustration of projected political expectations is even better explained. The entire ritual with its narrative-rhetoric structure is directed towards the ruling monarch (and his heir to the throne). When these highly stylized expectations, performed in secret space, not are fulfilled, disappointment is deepened and plays in the hands of already latent radicalization with the potential to erupt in public. 